\title{
The Desired Qualities of a Good Judge
}

\author{
Md.Manjur Hossain Patoari
}

Lecturer, Department of law, International Islamic University Chittagong, Bangladesh.

Email: manjuiiuc3@yahoo.com

\section{Mohammad Hasan Murad}

Assistant Professor, Department of Law, International Islamic University Chittagong, Bangladesh.

\author{
Md. Salahuddin Mahmud \\ Advocate Chittagong District Bar Association, Bangladesh \& Legal expert. \\ Email: advsmjewel@yahoo.com
}

\section{Doi:10.5901/ajis.2014.v3n1p97}

\section{Abstract}

A judge is a pillar of our entire justice system and the public expects highest and irreproachable conduct from anyone performing a judicial function. Judges must endeavor for the utmost standards of integrity in both their professional and personal lives. They should be knowledgeable about the law, willing to undertake in-depth legal research, and able to write decisions that are clear, logical and cogent. Their judgment should be sound and they should be able to make informed decisions that will stand up to close scrutiny. Judges should be fair and open-minded devoid of any kind of political fervor. In this article we have explored the qualities that an ideal judge should embody. We have also discussed the impediments to achieving and exercising such qualities and discussed a number of ways of for judges to be manifested as good judge.

Keywords: Justice, qualities of judge, public confidence, conscience, accountability and transparency.

\section{Introduction}

Centuries ago Justinian said that precepts of law are three in number i.e. to live honestly, to give every man his due and to injure none. These also sum up the ethical basis of legal system in modern times. Law in civilized society is intended to promote order, justice and liberty. The Judiciary is the last resort for obtaining redress of one's grievances .Today, the judiciary is called upon to enforce the fundamental rights and basic human rights of the poor and deprived section of the people and this new development has made the judiciary a more dynamic and important institution of the State than ever before. Judiciary as an organ of the state has to administer fair justice according to the direction of the Constitution and the mandate of law. Judges who are the pillars of judiciary are human beings and as such are not free from human errors and frailties. An independent and fearless Judge can best protect the right of the citizen. The errors or lack of due care, may, if or when it occurs, have disastrous consequences for a litigant. Judicial errors whether on purpose or otherwise often cause damage to the justice seekers. Sometimes the damage suffered is irreversible.

\section{Notion of Quality of Good Judge}

Every judge ${ }^{1}$ is a role model to the society to which he belongs. The same are embodied in all the religious scriptures. Socrates once stated that a judge must listen courteously, answer wisely, considers soberly and decides impartially. A judge is a public officer who is invested with authority to hear and determine litigated causes, and to administer justice between parties in courts held for that purpose? A judge is a person who presides over court proceedings, either alone or

\footnotetext{
${ }_{1}^{1}$ Judge means and includes sessions judges, Special judges, Tribunal Judges and Judicial magistrates-Rule 2(2) of the Criminal Rules
} and orders (practice and procedure of Subordinate Courts),2009 Vol.1. 
as part of a panel of judges. The powers, functions, method of appointment, discipline, and training of judges vary widely across different jurisdictions. The judge is supposed to conduct the trial impartially and in an open court. The judge hears all the witnesses and any other evidence presented by the parties of the case, assesses the credibility and arguments of the parties, and then issues a ruling on the matter at hand based on his or her interpretation of the law and his or her own personal judgment. ${ }^{2}$ The qualities of a good judge include patience, wisdom, courage, firmness, alertness, incorruptibility and the gifts of sympathy and insight. In a democracy, a judge is accorded great respect by the state as well as its citizens. He is not only permitted to assert his freedom and impartiality but also expected to use all his forensic skill to protect the rights of the individual against arbitrariness. Though such a state of affairs makes it easy for the judge to exercise his functions, he still requires many qualities to perform his duties effectively. ${ }^{3}$ The Judges repeatedly do what rests of people seek to avoid: make the decisions. ${ }^{4}$ The judiciary is the custodian of the Constitution and constitutional values. Hence, it is fundamental duty on judges to enforce fundamental duties. The time of a Judge is public time of which he is a trustee. Late Justice Hidayatullah once said-one who does not believe in punctuality of time does not have faith in the rule of law. Simon Rifkind laid down "The courtroom, sooner or later, becomes the image of the judge. It will rise or fall to the level of the judge who presides over it... No one can doubt that to sit in the presence of a truly great judge is one of the great and moving experiences of a lifetime. ${ }^{\prime 5} \mathrm{All}$ the religions ${ }^{6}$ of the world have explicitly laid dawn the specific message regarding the qualities of good judge.

\section{Importance of Qualitative Good Judge}

Dispensation of justice is an attribute of the Creator. ${ }^{7}$ For institutional and sustainable democracy, rule of law and good governance, there is no alternative of qualified and qualitative judge. It is the goal of our court to provide fairness, respect and dignity to the people who come before it. We strive to provide equal physical and procedural access to the court, so that all may have the opportunity to seek justice. ${ }^{8}$ The social service, which the Judge renders to the community, is the removal of a sense of injustice ${ }^{9}$ Judiciary handled by legal person is the custodian of life and property of the people at large and so the pivotal and central role as played by the judicial officers should endowed higher degree of qualities in consonance with the principles of "standard of care", "duty of care"10 and "reasonable person"11 as necessary with judicial functionaries. Lord MacMillan, a judicial member of the House of Lords said ---." Courtesy and patience must be more difficult virtues to practise on the Bench than might be imagined, seeing how many otherwise admirable judges have failed to exhibit them; yet they are essential if our courts are to enjoy public confidence."12 The American Bar Association once published an article called Good Trial Judges in which it discussed the difference in the qualities of a good judge and a bad judge and noted that practicing before a "good judge is a real pleasure," and "practicing before a bad judge is misery." ${ }^{13}$ Judicial accountability is a facet of the independence of the judiciary in the republican democracy. There are, therefore, recognized norms of judicial behavior expected from the judges. To maintain separation and independence of judiciary, the prime role should be played by the judges themselves. The rule of law which is the bedrock of democracy will be adversely affected if the independence of the judiciary is compromised by the erosion of the integrity of the

\footnotetext{
${ }^{2}$ Http://en.wikipedia.org/wiki/Judge accessed on 12.04.2012.

${ }^{3}$ Http://language123.blogspot.com/2008/06/qualities-of-good-judge.html accessed on 12.04.2012.

4 Judges, David Pannick, Oxford University Press, USA; 1st Ed. (U.K.) edition (February 18, 1988) p.1

${ }^{5}$ New Yorker, May 23, 1983, at p. 63.

${ }^{6}$ Muhammad Ibrahim H.I. Surty, "The Ethical Code and Organised Procedure of Early Islamic Law Courts, with Reference to alKhassaf's Adab al-Qadi", in Muhammad Abdel Haleem, Adel Omar Sherif and Kate Daniels (eds), Criminal Justice in Islam, I.B. Tauris \& Co Ltd, London and New York, 2003, pp 149-166 at 151-153.See also I. Twersky (ed), A MaimonidesReader, Behram House Inc., 1972, pp 193-194, cited in Weeramantry,An Invitation to the Law, pp 257-258. See also Matthew 7:12, in the Bible, Exodus 1.14, Roman 2.1, Leviticus19:15 and Deuteronomy 1:16.

7 Justice R. C. Lahoti, Judg" at http://www.judicialacademy.nic.in/SelectedSpeeches4.htm accessed on 17.04.2012.

${ }^{7}$ Rocky L. Crabb "The Desirable Qualities of a Judge" at http://www.smartvoter.org/ca/la, searchede: Supreme Court of India "The Culture Of A Judge" at http://www.judicialacademy.nic.in/SelectedSpeeches4.htm accessed on 17.04.2012.

8 ibid.

${ }^{9}$ Judges, David Pannick, Oxford University Press, USA; 1st Ed. (U.K.) edition (February 18, 1988)

${ }^{10}$ MacPherson v. Buick Motor Co. (1916,Winterbottom v. Wright (1842) and Donoghue v Stevenson [1932.

${ }^{11}$ Vaughn v. Menlove (1837).

${ }^{12}$ Law and Other Things, (1937), pp. 218-19.

${ }^{13}$ Litigation, V9No. 3 at 8 (1983).
} 
judiciary. And a judiciary equipped with a strong ethical tradition can never lose its moral strength or stature to dispense justice and is protected from attack from all quarter. Hsun Tzu, an eminent Chinese elder and respected magistrate (circa $312 \mathrm{BC}$ ) wrote thus: ${ }^{14^{4}} \mathrm{Fair}$ mindedness is the balance in which to weigh proposals; upright harmoniousness is the line by which to measure them. Where laws exist, to carry them out; where they do not exist, to act in the spirit of precedent and analogy - that is the best way to hear proposals. To show favoritism and partisan feeling and be without any constant principles - this is the worst you can do. It is possible to have good laws and still have disorder in the state.' Throughout the investigation, the judge is expected to scrupulously avoid the 'four avenues to injustice'. These are prejudice, hatred, fear and ignorance. ${ }^{15}$

\section{Matrix of qualities of a good Judge}

It is quite difficult and challenging to draw a stereotypical parallelogram of qualities of a good judge/justice as it varies in multitudes of time, place and circumstances. But from time immemorial in the zigzag path of justice in human civilization, we discover some common parlance to appraise the qualities of a good judge. In the Holy Quran the doctrine of Justice has been vigorously stressed. ${ }^{16}$

Article 2.02 of the Universal Declaration of the Independence of justice ${ }^{17}$ reaffirmed this universal principle as follows: Judges individually shall be free, and it shall be their duty to decide matters before them impartially, in accordance with their assessment of the facts and their understanding of the law without any restrictions, influences, inducements, pressures, threats or interferences, direct or indirect, from any quarter or for any reason. The Judges exercise the judicial power on trust. Normally when one sits in the seat of justice one is expected to be honest, trustworthy, truthful and a highly responsible person. The public perception of a Judge is very important as Marshal, Chief Justice of the United States Supreme Court said, "we must never forget that the only real source of power we as judges can tap is the respect of the people. It is undeniable that the Courts are acting for the people who have reposed confidence in them."18 That is why Lord Denning said, "Justice is rooted in confidence, and confidence is destroyed when the right-minded go away thinking that the Judge is biased". 19

More than any one else, a judge is a responsible person. His first accountability is, of course, to his own conscience. But that in itself is not enough, because conscience is not always invulnerable. What is also needed is accountability to the constitution, which, in reality, means accountability to public opinion, for the constitution is the ultimate analysis an embodiment of public opinion prevailing in a country. Lord Denning aptly said, "Every Judge, in a sense, is on trial to see that he does his job honestly and properly."${ }^{20} \mathrm{An}$ independent Judge must remain immune from political controversies. Today, Judges have got judicial immunity subject to correction of their judgment in appeal and revision. This doctrine of absolute judicial immunity has become entrenched in the common law world, yet, the Judges are accountable to conscience, to good sense and to the people at large. Justice Pn Bagawati, Chief Justice of India, reminds the Judges that to perpetuate an error is no heroism. To rectify is the compulsion of judicial conscience..$^{21}$ In order to purify the character of Judges and making the life disciplined he has asked the Judges to recollect the inspiring words of Justice Bronson who has stated- "A Judge ought to be wise enough to know that he is fallible and there fore, ever ready to learn; great and honest enough to discard all mere pride of opinion, and follow truth wherever it may lead, and courageous enough to acknowledge his errors". ${ }^{22}$ It is the duty of the Judge to know how to use his knowledge in the dispensation of justice and how to apply the law to change ever changing conditions, the never-changing principle of freedom. Now quoting from Bacon's Essay of Judicature "Judge ought to be more learned than witty, more reverend than plausible and more advised than confident. Above all things, integrity is their portion and proper virtue. Moreover, patience and gravity of hearing is also an essential part of justice, and an over speaking Judge is known as well tuned

\footnotetext{
${ }^{14}$ Basic Writings of Mo Tzu, Hsun Tzu and Han Fei Tzu, Burton Watson (trans), Columbia University

Press, 1967, p 35, cited in Weeramantry, An Invitation to the Law, p 253.

15 Human Rights and Religions in Sri Lanka, Sri Lanka Foundation, Colombo, 1988, p 67.

${ }^{16}$ Al Quran, 4: 58, 135.

${ }^{17}$ Adopted at 1st World Conference of the Independence of Justice, held at Montreal on June 10, 1983.

${ }^{18}$ Duren v. Missouri, 439 U.S. 352 (1979).

${ }^{19}$ L'Estrange v F Graucob Ltd [1934] 2 KB 394.

20 Ibid, note 12.

${ }^{21}$ Distributors (Baroda) P. Ltd. v. Union of India [1985] 155ITR120 (SC), ReCloth Traders [1979] 118 ITR 243 (SC).

22 Justice Bronson in Pierce v. Delameter (A. M. Y. p. 18.).
} 
cymbal."23 It is the duty of the entire Judge to follow the law who cannot do anything whatever he likes. In the language of Benjamin N. Cardozo: "The Judge even when he is free, is still not wholly free. He is not to innovate at pleasure. He is not a knight-errant, roaming at will in pursuit of his own ideal of beauty or of goodness. He is to draw his inspiration from consecrated principles."24

In ancient period the King was the source of justice. A strict code of judicial conduct was enjoined on the King. He was required to decide cases in the courtroom, his dress and demeanor were to be such not to over-awe the suitors or the accused. The King had to take oath of impartiality and to decide the cases without bias or attachment. On the importance of the judicial rode and preservation of mental equilibrium, the ancient Jurist Manu says "Having occupied the chair of justice with his body well- attired and mind composed, the Judges shall salute the guardian of deity (chair of justice) and then proceed with the trial." ${ }^{25}$ In the language of Katyan, the famous ancient Jurist, "a Judge should be austere and restrained, impartial in temperament, steadfast, God-fearing, and assiduous in his duties, free from anger, leading righteous life and of good family." ${ }^{26} \mathrm{~A}$ judge as an individual must maintain the principle of judicial independence and dispose of a case with the principle of fair play. The main feature of the judicial function is to provide judicial independence. This impartiality in the context of judicial independence means freedom of the judges to decide matters before them in accordance with their impartial assessment of the facts and their understanding of the law without improper influence of any quarters, direct or indirect, visible or invisible.

In all acts of judgment, the Judges should be transparent so that not only the lawyers but also the litigants can easily predict the outcome of a case. Transparency and predictability are essential for the judiciary as an institution of public credibility. After all, the judiciary is manned by human begins living in an orderly society. Setting aside his personal inclinations and prejudices, he must endeavor to achieve as much objectivity, as he can. Delay in pronouncement of judgment can also become a cause of suspicion in the mind of a litigant and, as such, inordinate delay in delivering judgment must be avoided as lack of transparency of activities of a Judge may give rise to doubts and misgivings in the mind of a litigant. The Twelve Tables (450 BC) contains the following injunction:27'The setting of the sun shall be the extreme limit of time within which a judge must render his decision. A Judge should not show favor to any particular lawyer. Judges must strive for the highest standards of integrity in both their professional and personal lives. They should be knowledgeable about the law, willing to undertake in-depth legal research, and able to write decisions that are clear and cogent. If a Judge leaves the law and makes his own decisions, even if in substance they are just, he loses the protection of the law and sacrifices the appearance of impartiality which is given by adherence to the law. ${ }^{28}$ Their judgment should be sound and they should be able to make informed decisions that will stand up to close scrutiny. As Benjamin Cardozo said with respect to the writing of reasons for judgment, "the sovereign virtue for the judge is clearness". ${ }^{29} \mathrm{Judges}$ should be fair and open-minded, and should appear to be fair and open-minded. They should be good listeners but should be able, when required, to ask questions that get to the heart of the issue before the court. They should be courteous in the courtroom but firm when it is necessary to rein in a rambling lawyer, a disrespectful litigant or an unruly spectator. It was in the $4^{\text {th }}$ Century B.C. when the wise Greek philosopher Socrates said that there are four qualities required in a Judge - "to hear courteously, to answer wisely, to consider soberly and to decide impartially". Bacon said - "Above all things, integrity is the Judge's portion and proper virtue. It is the capacity to decide impartially which is the most important criterion for judging the performance of the Judges on the Bench." 30 It is said, judging is lonely job and Judges, more often than not, are islands. a Judge has to be not only impartial but seen to be impartial. Patrik Devlin says "I put impartiality before the appearance of it simply because without the reality the appearance would not endure. In truth, within the context of service to the community the appearance is the more important of the two. The Judge who gives the right judgment while appearing not to do so may be thrice blessed in heaven but on earth he is no use at all." ${ }^{11}$ Chief Judge Richard Posner, a U.S. Federal judge and well-known law professor, in a review of Gerald

\author{
2323 Francis Bacon, "Of Judicature" (1612), P.15. \\ ${ }^{24}$ Chief Justice Benjamin N. Cardozo, "The Nature of the Judicial Process" ist. ed. 1921, p.10. \\ ${ }_{25}$ Manu, VII. 20. Georg Buhler (trans.) The Laws of Manu (Dover Press Publications, Inc., New York, 1969) p. 219. \\ ${ }^{26}$ www.allahabadhighcourt.in/.../ThelndianJudicialSystem_SSDhavan.doc. \\ ${ }^{27}$ The Civil Law, S.P. Scott (Trans), Central Trust Co., Cincinnati, 1932, Vol 1, pp 57-59, cited in \\ Weeramantry, An Invitation to the Law, pp 265-266. \\ ${ }^{28}$ The Judge, Patrick Devlin, pp. 5 \& 4. \\ 29 "Law and Literature" in The Selected Writings of Benjamin Nathan Cardozo 947) at 341. \\ ${ }^{30}$ Asian Age, New Delhi, 22-6-2002 (143 ELT A173), \\ ${ }^{31}$ The Judge, Patrick Devlin, p.3,
}


Gunther's biography of the undoubtedly great American judge Learned Hand (Learned Hand: "The Man and the Judge" (1994)), observed that "the obvious things" we look for in a candidate for a judgeship are "- intelligence, relevant experience, integrity, energy, maturity". ${ }^{32}$

\section{Challenges}

There are multifaceted impediments in case of attaining afore mentioned ideal qualities of a judge for materialization of far reaching horizontal and vertical level of expectation from the whole gamut of judiciary. The comparatively lowly status and remuneration of judges, and the judiciary's subordinate nature in the government structure, are among the early causes of judicial corruption. Do the Jugs get any systematic training during their process of making to build up a state of mind or attitude ${ }^{33}$ whereby they become committed to uphold the moral and ethical values and thus, the rule of law? Or in other words, how much concern, if at all, are our legal professional bodies and the legal education system to produce a lawyer or a law graduate who would never fail to appreciate the ethics in law?

Unfortunately, the existing legal education institutes of our country do not teach its graduates the ethics or professional responsibility. There is no conceptual framework that to be a good lawyer a student needs to learn and develop good ethics and as such, there is no subject called legal ethics in the official curriculum of any of the law degree of our country. To my knowledge no surprise inspection and visit was made to any subordinate Court without prior notice to ascertain the real activities of a subordinate Court. There is little scope of intellectual development here as the judicial officers cannot publish any articles, research papers unless and until pursuance of complex bureaucratic maneuver for consent from the authority is made.

In the District level courts; there are no minimum opportunities of rich library, modern information technology, residence and other ancillary opportunities. Judicial officers are suffering from lack of basic logistic support and if it is the reality the set parameter of Qualities of a Good Judge/Justice would be substantially unobserved and its expectation would be a 'castle in the air'. In Bangladesh, the expenditure on judiciary in terms of GNP is one of the lowest which is not more than 0.5 percent.

There is mammoth communication gap between the Bar and the Bench while there are no formal and informal steps to minimize the misunderstanding. The degenerated and colonial psyche is still activated and imbedded in all the decoration of judiciary. Frustrations, stoical and lackadaisical reality among the judicial officers are hindering judicial activism and qualitative speedy disposal which is constitutional commitment to the citizen at large. Social stratifications, class biasness, patriarchal chauvinism, all destructive bad omens of capitalism, globalization as neo-colonialism and corruption are tightening the rein of qualities of a good judge/justice.

Lack of positive and constructive criticism rather destructive and war mongering negative criticism about the judge and judiciary is a fundamental impediment of spontaneity to attain qualities of a Good Judge/Justice. Deliberations in our Courts marred and frayed by temper and loss of patience on either side is an unfortunate recent development, the odor it spreads bears an alarming message for the future generation of lawyers and Judges. Today, the political atmosphere outside is not very congenial for the growth of democracy and the effect of that is gradually corroding the Court arena which indeed is a very unhappy thing to happen. ${ }^{34}$

Lack of civility amongst the bar and bench for multifaceted causes is a mammoth problem to ring up the quality of good judge in Bangladesh. Herein Munroe Freedman, a prominent American law professor and co-author of Freedman and Smith opined that that the civility movement has gone too far. He and his co-author say that "the end result is the

\footnotetext{
32 Book Review, 104 Yale L.J. 511 at 524 (1994).

${ }^{33}$ Edgardo Buscaglia, 'Judicial Corruption in Developing Countries: Its Causes and Economic Consequences', paper posted by UN Global Programme against Corruption (2006). See www.unodc.org/pdf/crime/gpacpublications/ cicp14.pdf; Kalus Decker, Caroline Sage and Milena Steganova, 'Law and Justice: Building Equitable Legal Institutions', paper posted by the World Bank.Availableatsiteresources.worldbank.org/INTWDR2006/Resources/477383- 1118673432908/Law or_Justice_Building_Equitable _Legal_Institutions.pdf. The World Bank's strategic advice on legal reform states that when there is corruption within the judiciary, anticorruption campaigns must take a multipronged approach with a focus on judges, court staff and prosecutors that includes: training and education; appointment, promotion and salaries; evaluation and discipline; transparency in procedures and decision- making; and the participation of civil society. See World Bank, 'Legal and Judicial Reform: Strategic Directions' (2003). Available at www4.worldbank.org/legal/leglr/GreyBookFinal2003.pdf.
}

34 Supra, note 8. 
subordination of zealous representation to vague and sometimes unethical notions of civility". ${ }^{35}$ He notes that the supporters of civility creeds or guidelines insist that they are simply to exhort lawyers to behave with civility and that they are not intended to be enforced - but notes that judges have enforced principles of civility with sanctions. ${ }^{36}$ In Bangladesh,

We do not have any module on "Judicial Ethics and Code of Conduct of Judicial Officers". Two important external sources of judicial accountability are the role of the media and the role of civil society organisations, but these are highly feeble in our context. Last but not least, lack of patriotism, commitment and self sanction are quite visual.

\section{Recommendations}

Every judge is a role model to the society to which he belongs. The judges are certainly, accountable but they are accountable to their conscience and people's confidence. As observed by Lord Atkin: "Justice is not a cloistered virtue and she must be allowed to suffer the criticism and respectful, though outspoken, comments of ordinary men." ${ }^{37}$ With regard to the accountability of the Judges of the subordinate Courts and Tribunals it may be mentioned that Article $109^{38}$ of authorizes the High Court Division to use full power of superintendence and control over subordinate Courts and Tribunals. Under Article 109 of the Constitution a guideline in the nature of Code of Conduct can be formulated for the Judges of the subordinate courts for the effective control and supervision of the High Court Division. In this method, the judicial accountability of the Judges of the subordinate courts could be ensured. The Supreme Court of Bangladesh under Article 109 of the Constitution can also issue an appropriate order if it thinks that some sort of directions is necessary for the better administration of justice.

The professional bodies ${ }^{39}$ have to play a pivotal role to ensure that their members, before joining their respective profession, go through a proper system of training where they are carefully introduced to the issues of legal ethics and professional responsibility. Nobody can deny that there is a need for the development of an ethical framework in our entire legal and judicial arena. The utmost need for popularizing legal ethics and basic professionalism cannot be treated so callously.

The legal education in Bangladesh should enshrine the courses on ethics and legal ethics as compulsory. Judiciary as a whole of a country must remain accountable to the Code of Conduct and judicial ethics. The judiciary must be manned by persons of high quality, courage, determination, devotion and independent and unbiased mind. The judicial system as of today is a combination of the Judges and lawyers. It is the Bar which makes the judges. The judges shine with the reflected glory of erudition of the learned members of the Bar. If the Bar does not become helpful the Bench dwindles into mediocrity.

The judges and those in the profession of law belong to the same fraternity. We are all contributing our little mites to building up a just society. It is imperative that these two wings co-operate and co-ordinate with each other to ensure the dignity and independence of the Bench. An independent Bar is as essential for the administration of justice as an independent judiciary. I should like to add that no judiciary can be independent unless the Bar of that country is also independent. In fact, an independent Bar can greatly contribute to the independence of the judiciary. Evidently, both are responsible for protecting the constitution more than ever before. Judicial officers' access to modern information technologies like computer data base and internet etc. should be ensured to flourish human resource quality and for justice seems to be done.

There should be holistic and comprehensive efforts to ameliorate the overall socio-economic, political and egalitarian reality to attain the qualities of a good judge/justice. The presiding officer should help young lawyers for decent future social engineer as a little help from the bench will provide them with insight in law and take them a long way. ${ }^{40}$ By all means the prestige and honour of the courts from top to bottom must be preserved, protected and enhanced commanding the trust and confidence of the people in the days ahead for which the lawyers and judges must work

\footnotetext{
35 Understanding Lawyers' Ethics, 2nd ed. (2002), p. 121.

${ }^{36}$ Ibid, notep. 122.

${ }^{37}$ Cited by Chief Justice P. N. Bhagwathie, "Democracy and the Rule of Law" presented in Colombo, Sri Lanka, on 4 -1-1997.

${ }^{38}$ Article 109 of the Constitution of the people's Republic of Bangladesh.

${ }^{39}$ Such as the Bangladesh Bar Council, Bar Associations, the Judicial Administration Training Institute, etc.

40 Justice K. M Hasan, CJ, on 24.0.2004 on the eve of his retirement in Court Room No.1, "Search of justice, rule of law and independence of judiciary- guiding principles", BLD Journal, pp. 25-26.
} 
together in harmony and cooperation. ${ }^{41}$

The judicial officers should comply the prescribed code of conduct without derogation, which should be mandatorily monitored by the concerned authority ${ }^{42}$ and any kind of misdeed should be brought to the book as Kautilya, in the best known ancient Indian treatise on the principles of law and government, Arthasastra (circa 326-291 BC), refers to the judiciary thus: ${ }^{33 " W h e n ~ a ~ j u d g e ~ t h r e a t e n s, ~ b r o w b e a t s, ~ s e n d s ~ o u t, ~ o r ~ u n j u s t l y ~ s i l e n c e s ~ a n y ~ o n e ~ o f ~ t h e ~ d i s p u t a n t s ~ i n ~ h i s ~ c o u r t, ~}$ he shall first of all be punished with the first amercement. If he defames or abuses any one of them, the punishment shall be doubled. If he does not ask what ought to be asked, or asks what ought not to be asked, leaves out what he himself has asked, or teaches, reminds, or provides any one with previous statements, he shall be punished with the middlemost amercement."

A judge needs to update himself with not only the changes in the law but also constantly keep abreast with judicial ethics. Justice J.B. Thomas of Australia: "Some standards can be prescribed by law, but the spirit of, and the quality of the service rendered by; a profession depends far more on its observance of ethical standards. These are far more rigorous than legal standards.... They are learnt not by precept but by the example and influence of respected peers. Judicial standards are acquired, so to speak, by professional osmosis. They are enforced immediately by conscience." 44

Promotion and transfer should not be anchored with executive organ at any cost as sine qua non of independent judiciary otherwise a good judge has to endure various sufferings. The concerned authority should launch a module of "Judicial Ethics and Code of Conduct of Judicial Officers" with global standard and experience ${ }^{45}$ without any delay.

\section{Concluding Remarks}

Summing up the above references a Judge can be defined in the following language: "A judge should be God-fearing, law-abiding, abstemious, truthful in tongue, wise in opinion, cautious, fore-bearing, blameless and untouched by greed. In the words of Addison, 'to be perfectly just is an attribute of the divine nature, to be so to the utmost of our abilities is the glory of man'. A pusillanimous and corruptible judge is no bulwark of justice. We are in a new era where 170 millions people of Bangladesh nourish the dream of judiciary with 'justice seems to be done', speedy disposal with quality, accountability, transparency and cost effective which would be devoid of corruption, undue influence, profligacy, rampancy of illegal money/ bribe, unnecessary delay, pettifoggers, humiliation of humanity and crying of the illegally deprived. We no longer want to hear 'justice cries in silence' and 'court is dead; rest in silence' which are frequently echoing among the millions of down trodden justice seekers in Bangladesh. Simultaneously, we should not be oblivious about the great parameter in the language of Chief Justice Mr Nasirullah Beg of Allahabad High Court that the best test for determining the height of civilization in a society is to be found in the extent of honor, respect and regard paid in that society to the Judiciary;-the greater the respect, higher the civilization.

\footnotetext{
41 Ibid, p. 2.

42 It is recorded in the "Mirror of Justices" that King Alfred the Great, the Saxon King hanged forty four judges in one year foe reasons of violating the cod of conduct prescribed for the judges.

43 The Arthasastra, R.Shamasastry (trans.), Mysore Printing and Publishing House, 1967, pp.254-255,

cited in Weeramantry, An Invitation to the Law, p 245.

44 Judicial Ethics in Australia, 2d ed. Sydney: LBC Information Services, 1997.

45 Some examples are (a) The Code of Judicial Conduct adopted by the House of Delegates of the American Bar Association, August 1972,(b) Declaration of Principles of Judicial Independence issued by the Chief Justices of the Australian States and Territories, April 1997,(c) Code of Conduct for the Judges of the Supreme Court of Bangladesh, prescribed by the Supreme Judicial Council in the exercise of power under Article 96(4)(a) of the Constitution of the People's Republic of Bangladesh, May 2000,(d) Ethical Principles for Judges, drafted with the cooperation of the Canadian Judges Conference and endorsed by the Canadian Judicial Council, 1998, (e) The Idaho Code of Judicial Conduct 1976, (f) Restatement of Values of Judicial Life adopted by the Chief Justices Conference of India, 1999,(g) The lowa Code of Judicial Conduct,(h) Code of Conduct for Judicial Officers of Kenya, July 1999,(i) The Judges' Code of Ethics of Malaysia, prescribed by the Yang di-Pertuan Agong on the recommendation of the Chief Justice, the President of the Court of Appeal and the Chief Judges of the High Courts, in the exercise of powers conferred by Article 125(3A) of the Federal Constitution of Malaysia, (j) United Nations Basic Principles on the Independence of the Judiciary, endorsed by the UN General Assembly, 1985
} 
